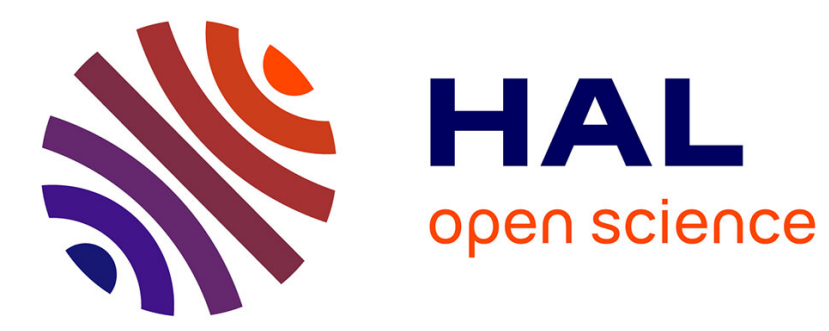

\title{
Neutron and X-ray experiments at high temperature P. Aldebert
}

\section{To cite this version:}

P. Aldebert. Neutron and X-ray experiments at high temperature. Revue de Physique Appliquée, 1984, 19 (9), pp.649-662. 10.1051/rphysap:01984001909064900 . jpa-00245234

\section{HAL Id: jpa-00245234 https://hal.science/jpa-00245234}

Submitted on 1 Jan 1984

HAL is a multi-disciplinary open access archive for the deposit and dissemination of scientific research documents, whether they are published or not. The documents may come from teaching and research institutions in France or abroad, or from public or private research centers.
L'archive ouverte pluridisciplinaire HAL, est destinée au dépôt et à la diffusion de documents scientifiques de niveau recherche, publiés ou non, émanant des établissements d'enseignement et de recherche français ou étrangers, des laboratoires publics ou privés. 


\title{
Neutron and $X$-ray experiments at high temperature
}

\author{
P. Aldebert $(*)$ \\ LA 302, E.N.S.C.P., 11, rue Pierre et Marie Curie, 75231 Paris Cedex 05, France
}

\begin{abstract}
Résumé. - Des technologies de pointe, dont certaines sont développées dans l'aérospatial ou le nucléaire, nécessitent une connaissance approfondie du comportement à très haute température de matériaux tels que des céramiques, des alliages réfractaires ou encore des métaux fondus. Parmi les techniques de haute température, la diffusion des rayons $\mathrm{X}$ et plus récemment celle des neutrons sont devenues des sondes puissantes propres à fournir des informations, principalement structurales, sur ces matériaux dans les conditions réelles de leur utilisation. A cet effet des dispositifs de haute température (au-dessus de $2000 \mathrm{~K}$ ) ont été réalisés qui utilisent diverses techniques de chauffage (par induction, avec des fours à image, des lasers, des chalumeaux à gaz et surtout par effet Joule) : certains sont décrits dans cette revue. Plusieurs points cruciaux dans ce type d'expérience sont abordés ici, ainsi : - la détermination de la température réelle (par thermocouples et par pyrométrie optique) dans la partie soumise au rayonnement de l'échantillon qui est difficilement accessible, notamment en raison des inévitables gradients thermiques,

- la réactivité chimique de l'échantillon avec son environnement, en fait l'atmosphère ambiante et le support de l'échantillon.

Les neutrons, principalement en raison de leur faible absorption par la matière, permettent l'étude de matériaux massifs donc réels et donnent, par rapport aux rayons $\mathrm{X}$, une liberté plus grande dans la conception des dispositifs de haute température. Actuellement des réacteurs à haut flux de neutrons thermiques dans une large gamme de longueurs d'onde existent, et une nouvelle génération de multidétecteurs de plus en plus performants est apparue au cours de la dernière décade; le temps d'acquisition des données et en conséquence la durée de l'expérience à haute température ont été considérablement réduits ouvrant ainsi la voie à des expériences précises et reproductibles dans la zone des $3000 \mathrm{~K}$. Ce domaine de très hautes températures déjà exploré par quelques autres techniques peut l'être également par les techniques de diffusion des neutrons.
\end{abstract}

Abstract. - Advanced technologies, like for instance aerospace or nuclear engineering require the most exhaustive information on the behaviour of materials used at very high temperature such as ceramics, refractory alloys or molten metals. Among high temperature techniques, $X$-rays and more recently neutron scattering have appeared as powerful tools to get information, mainly structural, on these materials in their working conditions. High temperature devices (above $2000 \mathrm{~K}$ ) developed for that purpose, based on various heating techniques (induction, imaging furnaces, lasers, gas-flame heaters and principally Joule heated devices) are reviewed. Some crucial points are particularly emphasized such as :

- the determination of the real temperature (thermocouples and optical pyrometry) in the scattering zone hardly accessible partly due to the unavoidable thermal gradients,

- the chemical reactivity of the sample with its surrounding, i.e. atmosphere and sample holder.

Neutrons, mainly because of their low absorption by matter, allow the work on real bulky materials and give a greater freedom in the conception of high temperature scattering devices compared to X-rays. At the present time thermal neutron high flux reactors offering a wide range of neutron wavelengths are available, and a new generation of more and more efficient multidetectors has emerged in the last decade; the data acquisition and consequently the high temperature exposure time have been notably reduced, opening a way for precise and reliable experiments in the $3000 \mathrm{~K}$ range. This very high temperature domain already studied by a few other techniques can also be investigated by neutron scattering.

(*) The author's personal work has been done at the ILL (HFR Grenoble). Now with the Equipe de Physico-Chimie Moléculaire, CENG-DRF, 85X, 38041 Grenoble Cedex, France. 


\section{Introduction.}

An extraordinary research effort on thermophysical properties of materials at very high temperature began just after the second world war. Several high temperature techniques have been developed for determination of physical properties such as melting points [1, 2], vaporization characteristics [3], or vapour pressures [4], thermodynamic data [5-9], electric conductivity [1013], thermal conductivity [14-16] and thermal expansion [17-21] in temperature ranges above $2000 \mathrm{~K}$. The begining of very high temperature $\mathrm{X}$-ray diffraction experiments [22] first contributed to the measurement of thermal expansion of refractory metals [23], progressing to the study in situ of high temperature phase transitions. High temperature neutron diffraction experiments have more recently been developed [24]. Although neutron scattering heating devices are significantly inspired by the numerous approaches tried for $\mathrm{X}$-rays, the neutron devices are at present simpler as will be shown in the present review. Anyway these two high temperature techniques are confronted with the same problems, namely determination of the real temperature of the sample in the scattering zone, thermal gradients, temperature stability and chemical reactivity of the sample with atmosphere and its holder.

\section{High temperature production for $\mathrm{X}$-ray and neutron scattering devices.}

2.1 X-RAYS. - Four kinds of heating techniques have been used in X-ray diffraction experiments :

i) induction heating, with electrically conducting samples that are directly heated when placed in the centre of the work coil; insulators can only be indirectly heated by thermal conduction and mainly by radiation. It is of interest to note that the latter method was the first to be used both for high temperature $X$-ray $[22,23,25]$, and neutron diffraction experiments [24]. The Bowman et al.'s neutron diffraction furnace [26] is shown in figure 1. A more recent high temperature $\left(T \leqslant 2500^{\circ} \mathrm{C}\right)$ induction heated X-ray device [27, 28] suitable for both conductive and non conductive samples is presented in figure 2 .

ii) radiation heating, these include : imaging furnaces (thermal radiation provided either by a carbon arc [29] or a short arc xenon lamp [30] (Fig. 3)) and also by solar heating up to $3000 \mathrm{~K}$ in air [32] and lasers up to $3300^{\circ} \mathrm{C}$ in air [33].

iii) gas flame heating, initiated by Gubser et al. [34] up to $2000^{\circ} \mathrm{C}$ and then developed by a Japanese research group up to $2300 \mathrm{~K}$ on a four circle diffractometer $[35,36]$ for crystal structure studies of refractory oxides [37] as well as for structural investigations on molten refractories [38]. In addition, this heating equipment is attachable to Weissenberg and precession cameras, with no heat damage to the surrounding equipment [39].

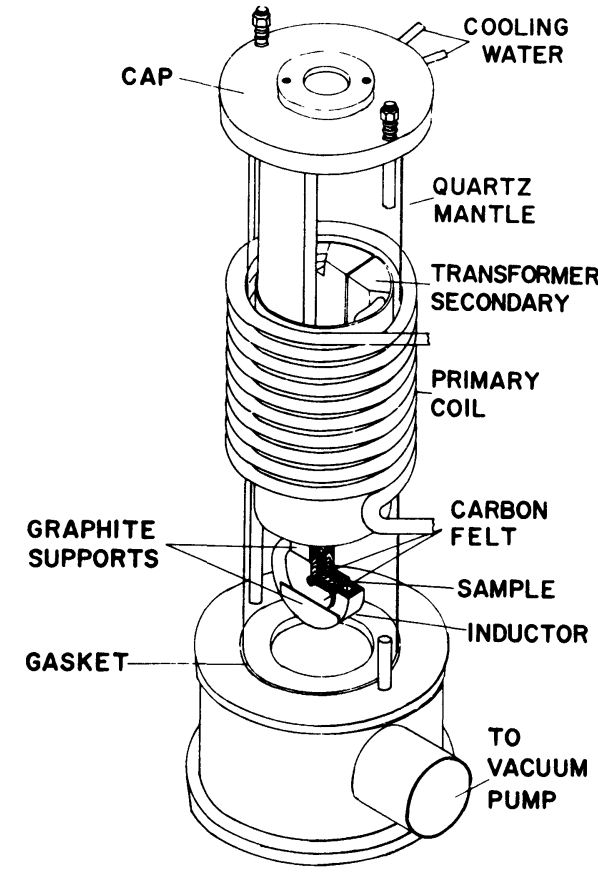

Fig. 1. - Bowman et al. high temperature neutron diffraction furnace (up to $2200^{\circ} \mathrm{C}$ ) from reference [26].

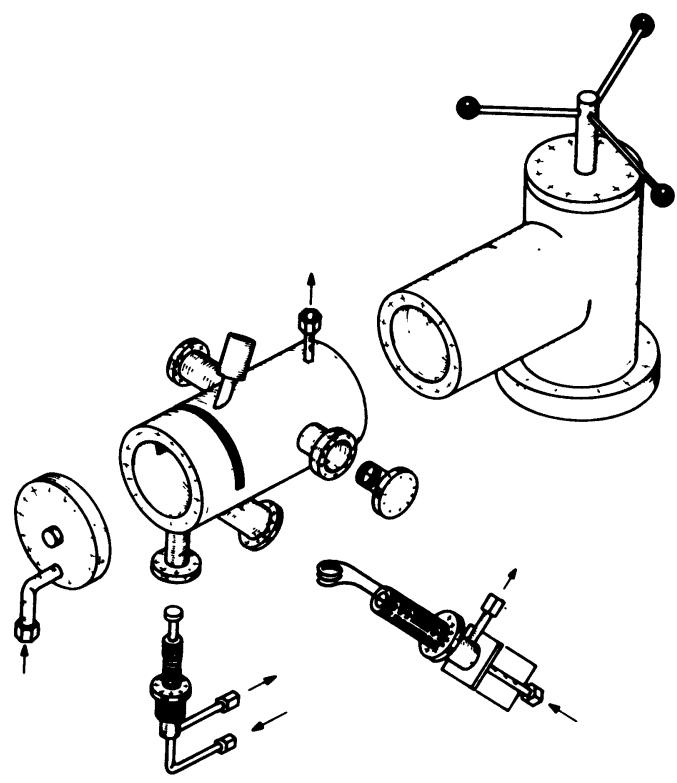

Fig. 2. - Sketch of a high temperature X-ray induction furnace [27] (this figure is supplied by Dr. J. Laugier). Bottom : the water cooled sample holder (susceptor). Bottom right : the water cooled inductor. The three elements constituting the furnace enclosure, water cooled too, exhibit several outputs (pumping, temperature determination by optical pyrometry...).

iv) direct or indirect resistance heating is by far the most widely used technique. The first X-ray very high temperature devices have generally worked with modified Debye-Scherrer or Seeman-Bolhin type cameras [40, 41]. This latter camera type associated with a counter has greatly contributed to the deve- 


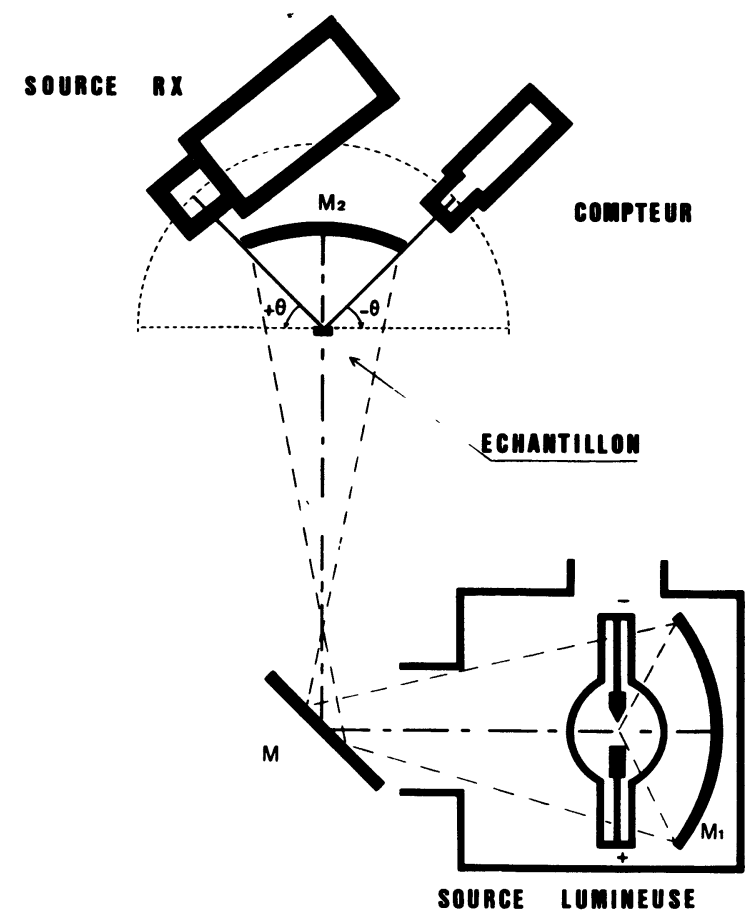

Fig. 3. - Sketch of a high temperature X-ray diffractometer (up to $3200^{\circ} \mathrm{C}$ ) heated with an imaging furnace [31] (this figure with French indications is supplied by Prof. A. Revcolevschi).

lopment of the technique. The sample is positioned inside a small cylindrical furnace with a wide slot on the top in order to allow the passage of the X-ray beam to and from the specimen as shown in figure $4[42,43]$. Three other devices of the same type need a special mention : one is carefully designed by Houska et al. [44] in order to make quantitative intensity measurements around $2000^{\circ} \mathrm{C}$. The second was especially built by Boganov et al. [45] for extremely high temperatures $\left(2750^{\circ} \mathrm{C}\right)$ generated both by Joule and electron beam heating for studying the phase transition of hafnia near its melting point. The last one is particularly well adapted for precise determination of thermal expansion coefficients of various refractory materials (mainly metals and oxides) up to $2500^{\circ} \mathrm{C}[46,47]$.

Several direct resistance heating devices have been made either in transmission or reflection geometry, mainly for very high temperature investigations on

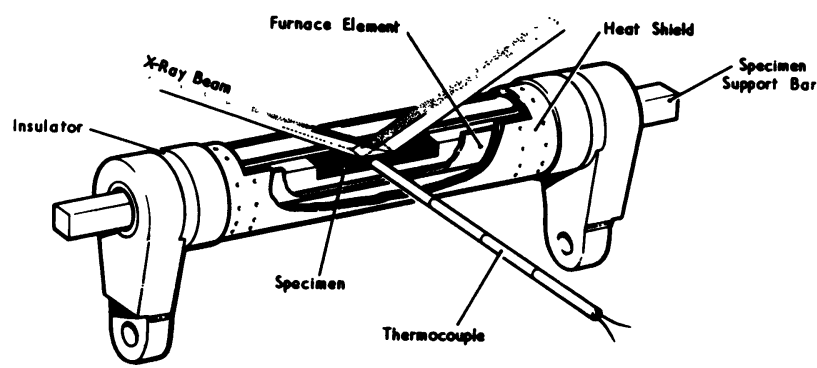

Fi.g 4. - Baker et al. specimen arrangement in their high temperature X-ray diffractometer from reference [42]. carbon up to $2600-2800{ }^{\circ} \mathrm{C}$ [48-54]; the samples in these devices indeed directly act as heating resistances.

Lastly, a particularly important technique of resistance heating is the utilization of refractory metal ribbons which act both as resistance heaters and supports for powdered samples only. Although an indirect heating technique, this method closely resembles the direct one. It was first introduced by Intrater et al. [55] and has been developed into a commercial high temperature diffraction chamber [56] widely used in laboratories [57]. Among several possible shapes of metal ribbon heaters, the flat ribbon with symmetrical holes designed by Traverse et al. [58] for a more sophisticated device (Fig. 5) improves a number of characteristics :

- firstly, the high temperature diffraction geometry since the clamp blocks can be moved in order to compensate more accurately the thermal expansion of the metal ribbon compared to the Intrater et al.'s [55] ones.

- secondly, the homogeneity of the powdered sample temperature in the diffraction zone owing to the holes machined in the ribbon.

- lastly, the determination of the true sample temperature due to the original optical device which associates a micropyrometer and a laser (Fig. 5). The principle of the method will be briefly discussed in paragraph 3.

Three high temperature X-ray devices mentioned above are shown on photographs (Figs. 6, 7, 8). High

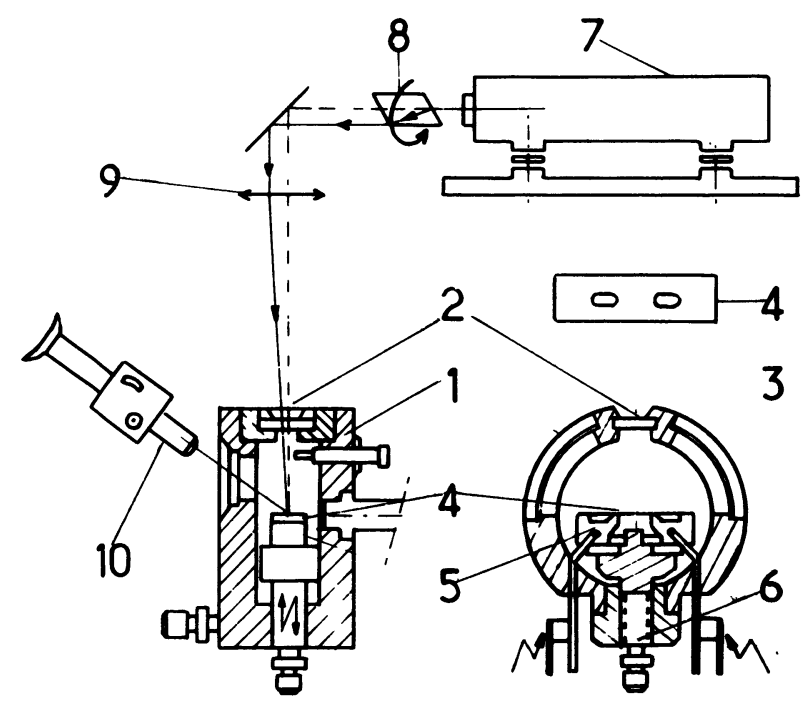

Fig. 5. - Sketch of the Traverse et al. [58] high temperature $\mathrm{X}$-ray metal ribbon heated diffraction device (side and front view). 1) furnace enclosure ; 2) transparent silica windows; 3) X-ray beam windows; 4) metal ribbon; 5) water cooled clamp blocks; 6) elevation control knob; 7) $\mathrm{He} / \mathrm{Ne} 60 \mathrm{~mW}$ laser $(\lambda=6328 \AA)$; 8) parallel side optical strip; 9) lens; 10) micropyrometer (this figure is supplied by Prof. J. P. Traverse). 


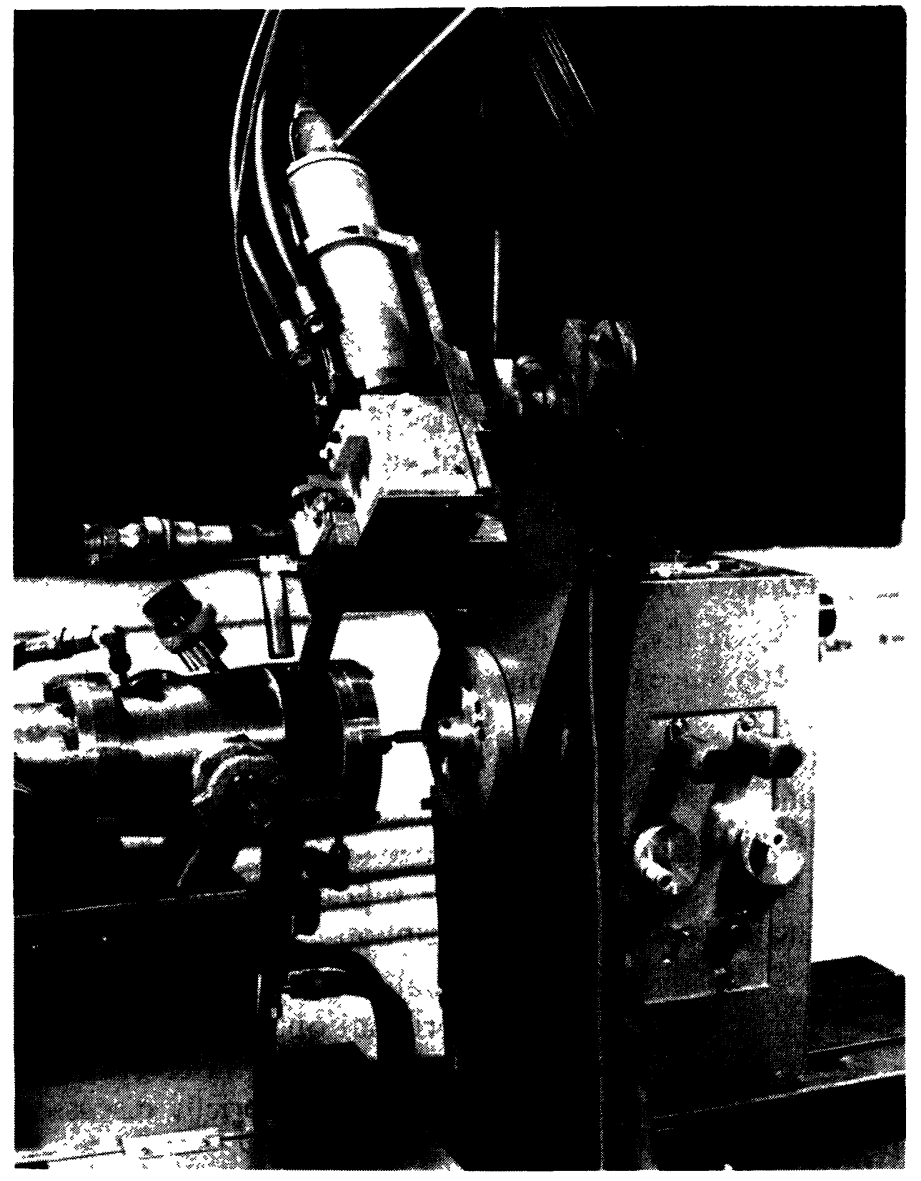

4 Fig. 6. - Photograph of the whole $\theta-\theta$ high temperature $\mathrm{X}$-ray induction heated goniometer [27-28]) this figure is provided by $\mathrm{Dr}$. J. Laugier); on left the induction furnace described on figure 2 .

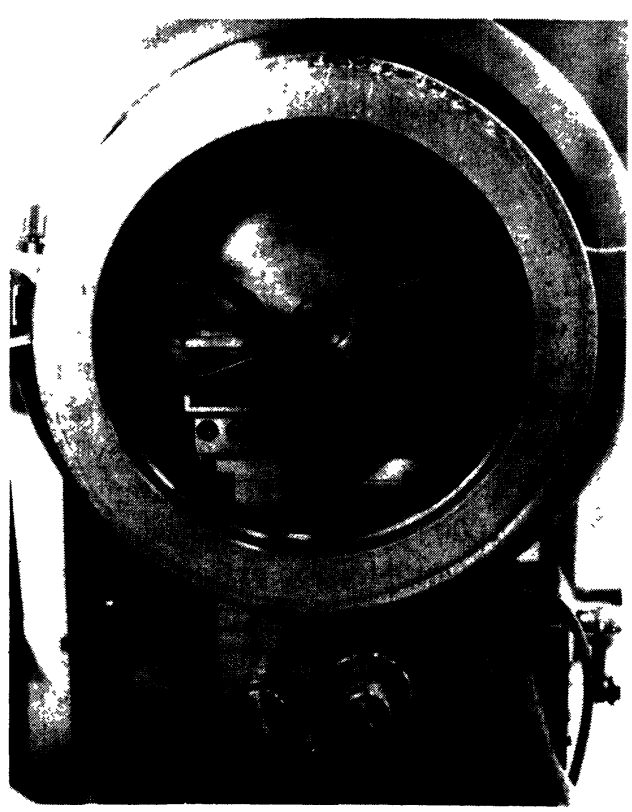

Fig. 8. - Photograph of a modified high temperature Xray diffraction chamber of the Norelco type [55-56] sketched on figure 5 ([58] this figure is provided by Dr. J. M. Badie).

4 Fig. 7. - Photograph of the $\theta-\theta$ Bragg Brentano high temperature $\mathrm{X}$-ray diffractometer heated with an imaging furnace sketched on figure 3 [30-31] (this figure is provided by Prof. A. Revcolevschi). Bulk samples covered with a $0.2 \mathrm{~mm}$ thick pyrex dome ( $75 \%$ of the X-ray beam intensity is absorbed) can either be studied under ambient or oxygen atmosphere. 
temperature diffraction patterns obtained with a Norelco type chamber are given on figure 9.

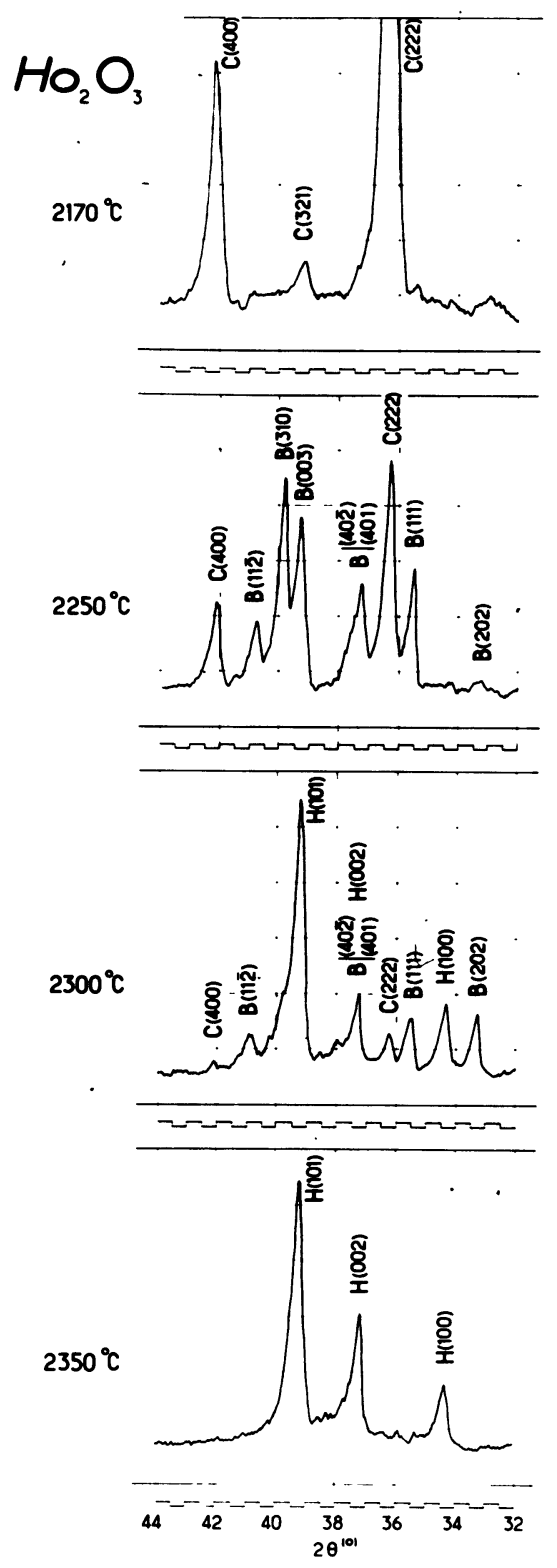

Fig. 9. - High temperature X-ray diffraction patterns of dysprosium sesquioxide heated under a slightly reducing atmosphere on a rhenium ribbon heater; C, B, H refer to polymorphic structures exhibited by rare earth sesquioxides ([59] this figure is provided by Prof. J. P. Traverse).

Several books or general articles which deal with high temperature $\mathrm{X}$-ray diffraction are given in references [60-66].

2.2 NeUtrons. - Up to now only two types of heating are used in neutron scattering experiments : induction and indirect resistance heating.

i) Induction heating, the pioneering work of Bowman et al. $[24,26]$ using a high temperature diffraction furnace, shown on figure 1 , must be cited first. High temperature crystal structure determina- tions as well as order-disorder transitions exhibited by several non stoichiometric refractory carbides such as $\mathrm{ThC}_{2}, \mathrm{LaC}_{2}, \mathrm{YC}_{2}$ and $\mathrm{Ta}_{2} \mathrm{C}$ were the purpose of these new kind of neutron diffraction experiments up to around $2500^{\circ} \mathrm{C}$. Similar equipment has been used by Tourand et al. [67] for the study of molten metals up to $2200^{\circ} \mathrm{C}$; it must however be noticed that the conductive sample is placed in a refractory metal or ceramic cylindrical holder inside the inductors. Mainly because of HF noises which disturb the data acquisition electronics, induction heating had been practically abandoned but because of recent improvements, a resurgence of this technique seems now possible [68].

ii) Indirect resistance heating. As for $\mathrm{X}$-rays, this is the far more widely used high temperature technique.

Several years ago structural investigations on molten metals and alloys using high temperature diffraction began [69]. Experiments on liquid Ni-V alloys (D4 diffractometer at the ILL) have required the construction of a high temperature apparatus (up to $2000{ }^{\circ} \mathrm{C}$ ) using a special tungsten heater fed with tantalum power supplies [69]. A sapphire container suitably cut and oriented is used in order to avoid parasitic Bragg reflections; this single crystal alumina container [70] is chemically resistant up to $1900 \mathrm{~K}$ with many corrosive molten metals. The high temperature device described in [69] has been adapted for small angle neutron scattering experiments (D11A camera at the ILL) on molten Au-Si alloys [71]. The more recent improvements of these high temperature furnaces are detailed in this special issue [72]. Finally, an original set up for neutron scattering experiments on fluid systems at high temperatures (up to $1970 \mathrm{~K}$ ) and pressures (150 bars) applied to molten rubidium must be mentioned [73].

Neutron scattering on solid refractory materials at very high temperatures is also an attractive field of investigation. A high temperature device using thin walled tungsten heater was first developed in 1975 [74]. High temperature phase transformations exhibited by several refractory oxides $\left(\mathrm{La}_{2} \mathrm{O}_{3}, \mathrm{Nd}_{2} \mathrm{O}_{3}, \mathrm{ZrO}_{2}\right.$, $\mathrm{HfO}_{2} \ldots$ ) in various atmospheres (neutral, reducing and oxidizing) and more especially the oxygen sublattice behaviour was the purpose of these studies. A more sophisticated device, shown on figure 10, has been achieved later on [75, 76]; figure 11 shows a versatile sample holder that has been designed in order to allow slow rotation of the sample, even at the highest temperatures $\left(\cong 2500^{\circ} \mathrm{C}\right)$. Versatility of the heating system has been improved too (Fig. 12) so that it can either work in neutral atmosphere (Fig. 12A : the furnace is filled with pure helium whose oxygen partial pressure is lowered by a $\mathrm{Zr}$ getter heated around $900^{\circ} \mathrm{C}$ ), reducing atmosphere (a graphite felt insulation is then used) or in oxidizing atmosphere (Fig. 12B) up to $1750{ }^{\circ} \mathrm{C}$ by using a $90 \% \mathrm{Pt}-10 \% \mathrm{Rh}$ resistor. The whole experimental set up working on the DIB diffractometer with a multidetector (HFR-ILL) is shown in figure 13. Since then similar types of high 


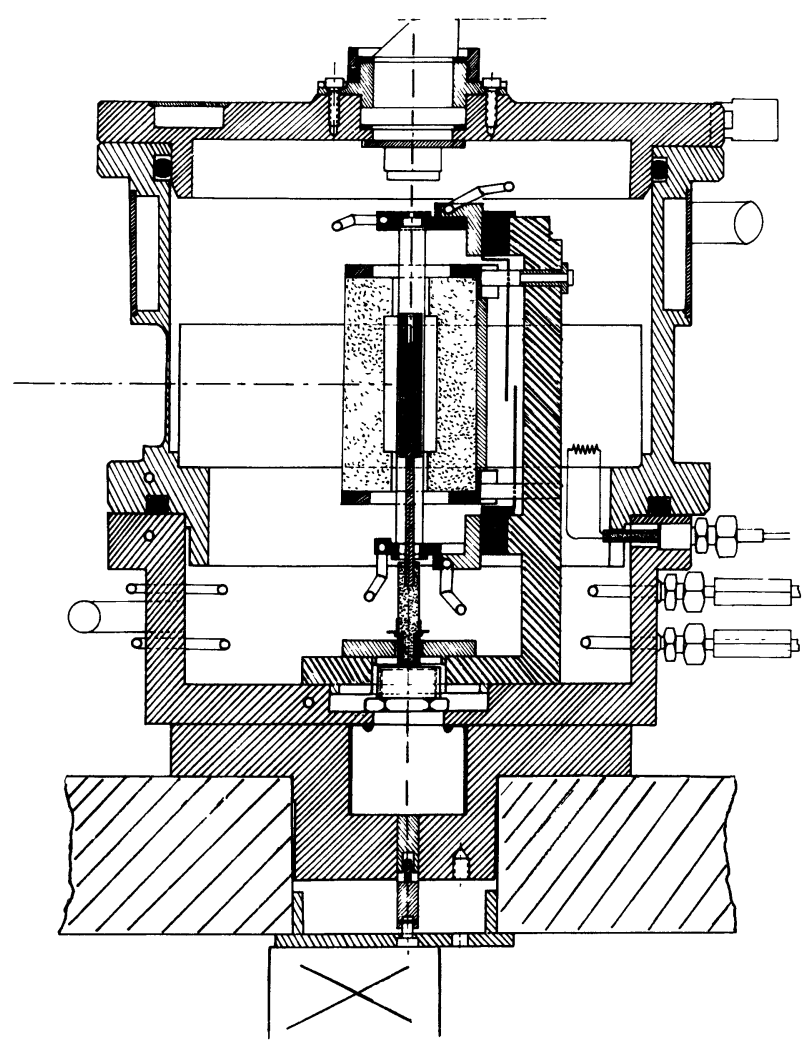

Fig. 10. - Sketch of the high temperature versatile set up for neutron scattering experiments on sintered samples [74-76]. The aluminium external furnace enclosure is water cooled; on left, a $1 \mathrm{~mm}$ neutron beam window with a $220^{\circ}$ angular range; on top, a silica (suprasil) window protected from vapours deposition with a movable obturator, and a total reflection prism for temperature determinations by optical pyrometry $(\lambda=6500 \AA)$; on right power supplies for the tungsten heating element and the zirconium getter.

temperature furnaces have been designed [77-80], mainly in order to study high temperature oxygen disorder in $\mathrm{UO}_{2}$ and $\mathrm{ThO}_{2}$. The work undertaken at the ILL in order to provide high temperature furnaces catering for the needs of external users must be emphasized [81]. A limited but interesting review on high temperature neutron diffraction studies has been published by Bowman et al. [82].

\section{Real temperature determination in the scattering zone above $2000 \mathrm{~K}$.}

Only two temperature measurement techniques thermocouples and optical pyrometry are available above $2000 \mathrm{~K}$ (recent sophisticated ultrasonic and thermal noise thermometries are purposely omitted). In this temperature range, they are of unequal importance, $3000{ }^{\circ} \mathrm{C}$ is the extreme temperature working limit for thermocouples [83] with severely restrictive conditions, whilst the limit for pyrometry is several thousand degrees beyond [84]. However, in both cases thermal gradients in the sample scattering zone

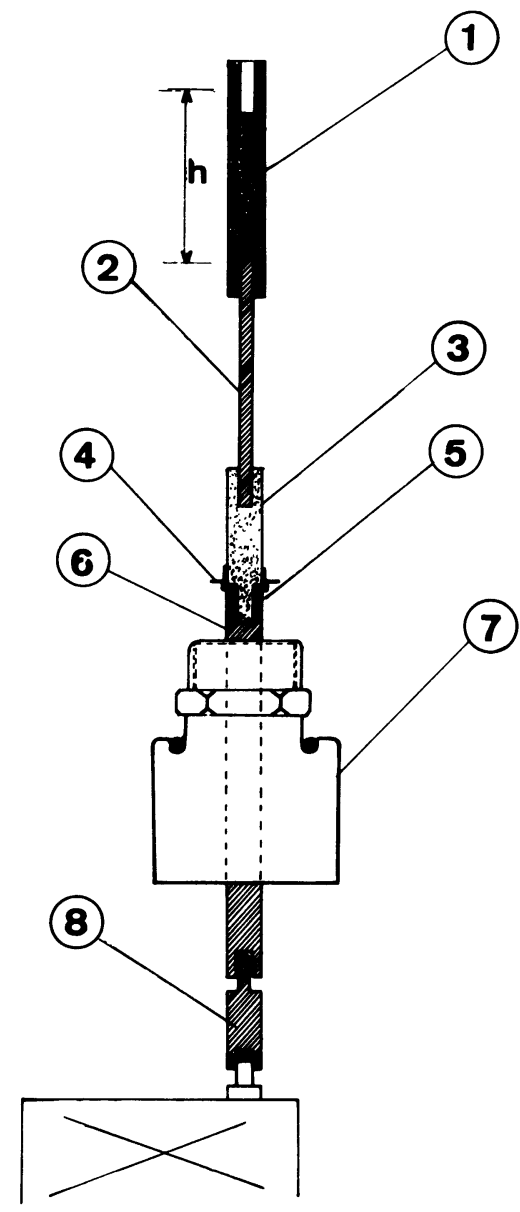

Fig. 11. - Description of the sample holder system used in the experimental set up shown on figure $10 ; 1)$ the sample with a pseudo-blackbody cavity on top, $h(40 \mathrm{~mm})$ being the scattering zone height; 2) refractory rod $\left(\mathrm{W}, \alpha \mathrm{Al}_{2} \mathrm{O}_{3}\right.$ or calcia stabilized zirconia (CSZ)); 3) $\alpha \mathrm{Al}_{2} \mathrm{O}_{3}$ holder; 4) aluminum reflector; 5) outlet metal connection with the rod 6 fitted to the furnace enclosure by means of rotary vacuum seal $7 ; 8$ ) connection with the motor.

are crucial points that can deeply affect the accuracy of the real temperature determination.

3.1 THERMOCOUPLES. - Generally two families of thermocouples are suitable for high temperature measurements. Firstly, the precious metals family, for instance the usual $\mathrm{Pt}, 10 \% \mathrm{Rh} / \mathrm{Pt}$ thermocouple, whose upper working limit is near $1900^{\circ} \mathrm{C}[29$, $83,85]$ mainly due to alloy melting points [86]. Chemically resistant in various media, they generally give reliable measurements up to their working limit only if used in oxidizing or neutral atmospheres and more especially when coated with an unreactive insulating ceramic such as $\alpha-\mathrm{Al}_{2} \mathrm{O}_{3}$ [83]. For higher temperatures up to $3000{ }^{\circ} \mathrm{C}$ refractory metal thermocouples can be used. These include W, $26 \% \mathrm{Re} / \mathrm{W}$ whose theoretical limit is about $2800^{\circ} \mathrm{C}$ [85] in spite of the very high melting points of $\mathrm{W}$ and $\operatorname{Re}$ (see Table III). However several physicochemical properties make their handling delicate and restrict their use to a far 


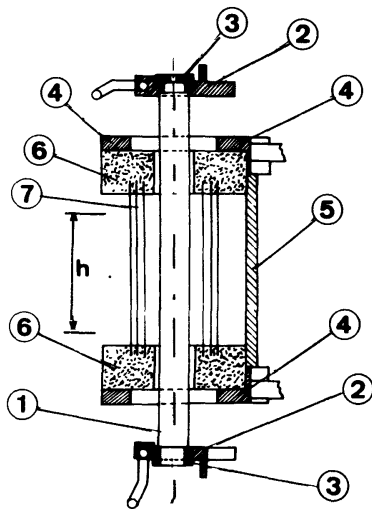

(A)

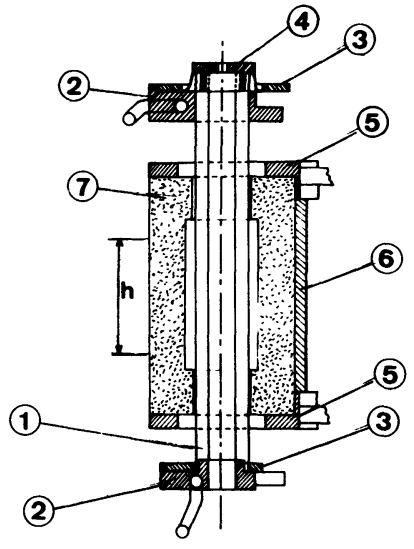

(B)
Fig. 12. - A) neutral atmosphere heating device (maximum temperature $\cong 2500^{\circ} \mathrm{C}$ ) : 1) W cylindrical resistor (length $130 \mathrm{~mm}, 10$ or $12 \mathrm{~mm}$ i.d., thickness $0.05 \mathrm{~mm}$ ); 2) water cooled power supplies; 3 ) drilled (1.5 mm i.d.) $\mathrm{Cu}$ clamp and cap ; 4), 5) insulation holder system (refractory molybdenum steel) ; 6) CSZ insulating felt (Zircar); 7) W shields (thickness $0.03 \mathrm{~mm}$ ) that can be replaced either by a full zircar insulation (see B) or a graphite felt for reducing atmosphere (Fig. 15 in Ref. [75]). B) oxidizing atmosphere heating device (maximum temperature $\cong 1750^{\circ} \mathrm{C}$ ) : 1) Pt$\mathrm{Rh}(10 \%)$ resistor with an hexagonal cross section and flange for thermal expansion on top; 2) ibid $\mathrm{A}$; 3) $\mathrm{Cu}$ resistor clamp; 4) $\alpha \mathrm{Al}_{2} \mathrm{O}_{3}$ drilled cap; 5), 6) ibid $\mathrm{A} 4,5$; 7) full zircar insulation.

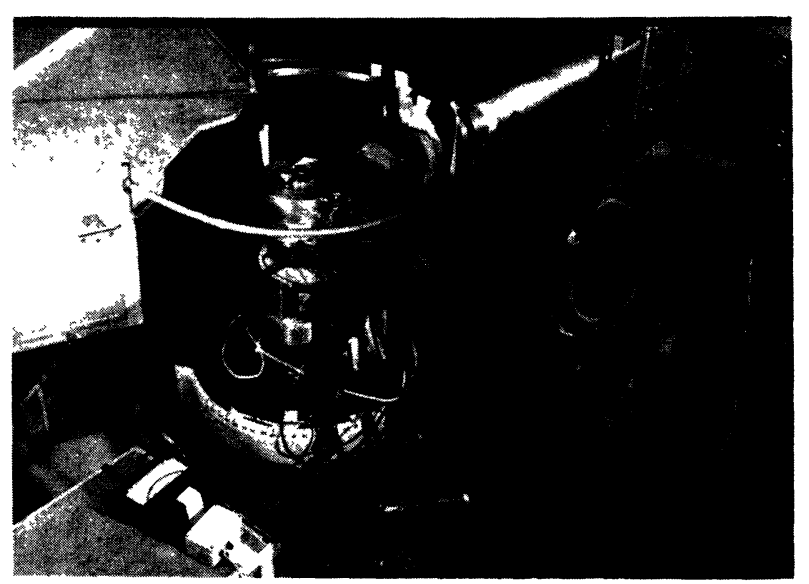

Fig. 13. - The whole high temperature neutron scattering device working on DIB (ILL).

lower temperature range. Stiffness of these thermocouples gives rise to difficulties in ensuring tight bead contacts inside the sample, particularly if rotating. Embrittlement, especially after heating, is also a strong handicap. Lastly, although usually less chemically reactive at high temperature than other refractory metals [87], especially with refractory oxides [3, $57,88]$ their degradation with time is always a major nuisance caused by easy formation of tungsten oxides with oxygen [89] even in traces, or diffusion into the samples $[75,76,89-91]$. This is why, with few excep- tions needing drastic precautions [6], employment of tungsten-rhenium thermocouples is particularly delicate above $2000{ }^{\circ} \mathrm{C}$, even when coated with reliable ceramic insulators such as $\mathrm{ThO}_{2}, \mathrm{BeO}$ or $\mathrm{Y}_{2} \mathrm{O}_{3}[83,92]$. Thus their use is recommended for temperature control for power supplies at temperature not exceeding $1900^{\circ} \mathrm{C}$.

Calibration of thermocouples is an important point of metrology. Owing to their more or less fast degradation or pollution in the course of long periods of use, noticeable inconsistancies in the measured e.m.f. are unavoidable, and measured temperatures thus become more and more unaccurate, even meaningless. Reliable high temperature methods for thermocouple calibration exist up to $2200^{\circ} \mathrm{C}[93,94]$ based upon pyrometric temperature determination using reference refractory materials [87].

3.2 OPTICAL PYROMETRY. - Optical pyrometry is the most suitable method for temperature determination above $2000 \mathrm{~K}$. Higher temperatures can be measured and the absence of direct contact between the specimen and the measuring instrument, is a clear advantage.

A few basic principles of pyrometry are only needed here to understand the capacities and limitations of this method. Exhaustive information can be obtained from particularly specialized books $[84,95]$ or from extensive articles [94, 96, 97]. Temperature can be measured by any system which has a measurable macroscopic parameter that exhibits a known variation with $k T, k$ the Planck's constant, $T$ being the thermodynamic temperature. This is the case for gas thermometry which obeys the perfect gas law, and for blackbody thermal emission. Planck's relationship (1900) expresses the total energy radiated distribution in all directions for a given temperature $T$ and wavelength $\lambda$, thus defining the spectral radiance $J(\lambda, T)$. This relation, simplified within Wien's approximation $(\lambda T<2000 \mu . \mathrm{K})$, can then be integrated in the whole $\lambda$ range, giving the Stefan-Boltzmann expression : $R(T)=\sigma T$, with $R(T)$ the total radiance (or integral luminence) and $\sigma$ the Stefan's constant. Energy radiated in a given direction is defined by the spectral luminence $L(\lambda, T)$ (brilliance $B(\lambda, T)$ in the past) and obeys Lambert's law if direction independent. This is only true for blackbodies but a good approximation for numerous incandescent bodies, especially finely divided oxides. Then it can be shown that $J(\lambda, T)=$ $\pi L(\lambda, T)$. Since the thermal emission of all bodies is sufficiently intense in the $0.3-20 \mu$ wavelength range, temperature determination can be achieved by radiative pyrometries, optical pyrometries in particular, that measure radiated energy by various methods :

i) spectral luminence $L$ determination of the sample compared to blackbody luminence $L^{0}$ at the same $\lambda$ and $T$ (monochromatic pyrometry),

ii) spectral luminence determination at two diffe- 
rent wavelengths, $T$ being constant (two-colour pyrometry),

iii) total radiance $R$ determination, in comparison with a blackbody at the same $\lambda$ and $T$ (total radiance pyrometry).

Monochromatic pyrometry, the most extensively used technique, requires the determination of $\varepsilon(\lambda, T)$, the monochromatic emissivity factor, $L(\lambda, T) / L^{0}(\lambda, T)$ by definition, $\lambda$ and $T$ being equal. Then applying the Wien simplified Planck's formula, Lambert's law being satisfied, the relation between real temperature $T_{\mathrm{R}}(\mathrm{K})$ and luminence temperature $T_{\mathrm{L}}(\mathrm{K})$ is expressed as follows : $1 / T_{\mathrm{R}}=1 / T_{\mathrm{L}}+\lambda \mathrm{Ln} \varepsilon_{\lambda} / C_{2}$ with $C_{2}$ the second Planck constant $(14388 \mu . \mathrm{K})$. The case of the ideal blackbody excepted $\left(\varepsilon_{\lambda}=1\right), \varepsilon_{\lambda}$ is generally unknown since it depends on different origin parameters (intrinsic physical properties of the real body, but also surfaces conditions and bulk shape for instance [98]). Thus $T_{\mathrm{R}}$ is systematically greater than $T_{\mathrm{L}}$, the temperature directly deduced from reading on a disappearing filament pyrometer which generally works with the $i=0.65 \mu$ red radiation. Actually two possibilities can provide reliable $T_{\mathbf{R}}$ determinations.

- More or less blackbody conditions can be achieved by means of cavities [98] drilled either into the sample itself when solid $[19,21]$ or in the sample container when molten $[3,8,9,12,99-101]$. This method is widely used in high temperature X-ray diffraction devices [23, 28, 41, 43, 44, 47, 52] and easily feasible with neutron scattering apparatus [69, 74-76]. However in order to get an emissivity factor $\varepsilon_{\lambda}$ significantly near unity, several conditions must be fulfilled : the blackbody enclosure, deep enough compared to its aperture diameter, must be uniformly heated and internal reflections completely diffuse rather than specular [97, 102-104]. Quinn's calculations [105] when applied to cavities of ceramic oxide samples shown on figure 11 (cavity depth $15 \mathrm{~mm}$ and aperture diameter $1.5 \mathrm{~mm}$ ) give $\varepsilon_{\lambda}=0.997$, thus introducing a negligible temperature correction $\left(<1^{\circ} \mathrm{C}\right.$ at $\left.2200^{\circ} \mathrm{C}\right)$.

- Direct determinations of the emissivity factor $\varepsilon_{\lambda}$ of the sample in working conditions can be made. Methods described here are based upon Kirchoff's law which connects monochromatic factors related to surface properties of real bodies : $\varepsilon_{\lambda}=\alpha_{\lambda}=1-\rho_{\lambda}$ with $\alpha_{\lambda}$ the monochromatic absorption factor and $\rho_{\lambda}$ the monochromatic reflection factor. This is only valid if the transmission factor is zero, which requires for instance, that a sample deposited onto a ribbon heating support is sufficiently thick. The incident modulated flux method developed by Cabannes [106, 98] is indeed suitable for samples whose reflective properties are, either fully specular, fully diffuse, or a simple addition of the two reflective modes. Practically, this method is difficult to use. Traverse has developed an improved method $[107,58]$ based upon the determination of the following luminence temperatures $T_{\mathrm{L}}$.
* The sample temperature $T_{\mathrm{S}}$.

* The apparent temperature of the sample $T_{\mathrm{A}}$ illuminated with a small $\mathrm{He} / \mathrm{Ne}$ laser $(60 \mathrm{~mW})$ whose spectral luminence is however extremely high.

* The reference luminence temperature $T_{0}$ of the laser measured at room temperature along the same sight geometry on a standard white surface which exhibits a high known $\rho_{\lambda}$ nearly equal to unity (for instance $\mathrm{MgO}$ in the red [107], or $\mathrm{BeO}$ whose $\rho_{\lambda}=0.98$ at $\left.\lambda=1 \mu[106]\right)$. From the measurement of these three luminence temperatures, corresponding spectral luminences are deduced, thus providing the sample $\varepsilon_{\lambda}$ from the relation : $\varepsilon_{\lambda}=1-\rho_{\lambda}=$ $1-\left(\left(L_{\mathrm{A}}-L_{\mathrm{S}}\right) / L_{0}\right)$ from which the real temperature is obtained. The laser wavelength being $0.6328 \mu$, a suitable filter must be fitted to the pyrometer. An illustration of the Traverse's experimental device is shown on figure 5 [58].

Two-colour pyrometry $[84,95,96]$ needs only a short mention since literature offers few applications of that technique in high temperature scattering experiments $[28,29]$. This mainly arises from the necessity of a constant $\varepsilon_{\lambda}$ at two wavelengths (usually red and blue). Only true grey bodies, actually uncommon, have this property.

On the contrary total radiance pyrometry is widely used both for laboratory and industrial temperature measurements [96]. This type of pyrometers is always quite automatic, with a rapid response time

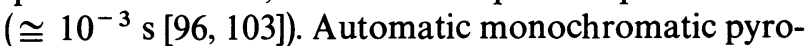
meters however favorably compete from that point of view [94, 97, 102] thus justifying their use when a continuous record of temperature changes is needed [103], for instance furnace control [104]. Direct determination of absolute temperature, impossible with radiance pyrometers only, can however be done if they are associated with calibrated monochromatic pyrometers : temperature determination in the X-ray diffraction device of Guichet et al. $[46,47]$ is a convincing demonstration.

$\varepsilon_{\lambda}$ determination is thus a crucial point in optical pyrometry [106]. Absorption by sight windows (generally "suprasil " silica which absorbs the less in the red is used) and (or) by total reflecting prisms has to be taken into account resulting in an equivalent $\varepsilon_{\lambda}$ that must be added to the $\varepsilon_{i}$ of the sample. This correction is applied by most of the authors cited in this review. For instance, the equivalent emissivity is reduced from nearly unity to 0.84 for the high temperature neutron scattering device shown on figure 10 [74-76]. It is then obvious that great care must be taken in order to protect the windows from internal and external vapour depositions (Fig. 10). Another crucial point occurs when samples are heated by radiation [2933] since reliable temperature determination requires the separation of the sample own emitted light from scattered light. One technique is to view the sample while temporarily blocking or disrupting the source of light $[29,103,108]$. Such a procedure is used by 
Revcolevschi et al. [108] : optical densities of photograph taken whilst incident light is screened $(0.02 \mathrm{~s})$ are compared to those of materials acting as spectral luminence references.

As for thermocouples, pyrometers must be carefully calibrated and the tungsten strip lamp [84, 95, 102] is the most widely used emissivity standard $[12,22$, $23,18,86]$. Although $\mathrm{W}$ emissivity is reliably known up to extremely high temperatures $[84,109]$, calibration of tungsten lamps with standard blackbodies $[84,95$, $102,104,105,110]$ is a necessity for accurate measurements. Actually both W strip lamps and pyrometer filaments grow old [86] thus requiring periodic checks with blackbodies. To this latter source of uncertainties must be added those arising from eye sensibility, including readings on the voltametric display of the pyrometer and poorly controlled sight geometry. Within some of the precautions and restrictions that have been mentioned, optical pyrometry remains a far more reliable temperature determination technique above $2000^{\circ} \mathrm{C}$ compared to thermocouples. This advantage is even more pronounced when neutron scattering devices are involved since sample size and shape generally allow pyrometric sights in excellent quasi-blackbody conditions, then avoiding most of radiative surface sources of uncertainties $[42,43,47]$. Direct high temperature determinations on single crystals using optical micropyrometers is however a nearly unique situation that cannot be satisfactorily overcome.

Complementary indirect temperature determination can be employed when both thermocouples and pyrometry provide doubtful data. These are mainly based upon the known evolution with temperature of thermal expansion of refractory materials such as $\mathrm{Ta}, \mathrm{W}$, $\alpha \mathrm{Al}_{2} \mathrm{O}_{3}, \mathrm{UO}_{2}, \mathrm{ThO}_{2}$ [27-29, 42-44, 55, 77-79] or upon the melting points of reference substances such as $\alpha \mathrm{Al}_{2} \mathrm{O}_{3}, \mathrm{Y}_{2} \mathrm{O}_{3}, \mathrm{ThO}_{2}[29-31,36,42,43,108]$. Therefore this procedure introduces uncertainties since problems with high temperature material standards problems are still unsatisfactorily solved $[11,16$, $20,86,111,112]$. Internal calibrations being impossible at high temperature, other sources of uncertainties then arise from the independence of the calibration and specimen runs [55]. Differences in shape, size and position can indeed easily occur. In such cases power consumption is not a reliable means of high temperature determination, just a temperature fluctuation indicator $[24,27,28,36,44]$. Consequently, temperature uncertainties are often greater than expected and increase with temperature. For greatest accuracy and reliability in high temperature determination, checking and combining the maximum number of independent measurements is strongly recommended $[29,42-44]$.

3.3 Thermal GRADIENTS. - Inhomogeneities are an other source of uncertainties on temperature measurements in high temperature scattering devices $[65,66$,
29]. Sample thermal gradients in the scattering zone arise from numerous origins, mainly the difficulty to achieve a perfectly insulated enclosure, especially with $\mathrm{X}$-rays which require, because of their severe absorption by matter, a beam path free from insulators or shields (Fig. 4 [42, 43]). Temperature determination apertures are needed for pyrometric sights, even in nearly blackbody conditions, as well as for thermocouple attachments; in this latter case local thermal disturbances are enhanced because of extra thermal losses by conduction [42-44, 55]. Additional thermal gradients can arise, for instance from poorly controlled thickness of powdered samples deposited onto ribbon heaters or from angular dependent scattering areas according to the diffraction technique.

Several precautions can significantly reduce thermal gradients. For example discontinuous sightings with a rapid response pyrometer enables one to avoid [25] radiative thermal losses during most of the acquisition time. Holes machined in the flat joule heated ribbons designed by Traverse (Fig. 5 [58]) as well as rotation of the sample when possible $[25,30$, $31,33,108]$ also improve temperature homogeneity. This latter solution is more feasible with neutrons (Fig. $11[75,76])$ and is probably more efficient. In addition the low absorption of neutrons by most materials allows a more rigourous insulation. In addition to the widely used $W$ refractory shields $[44,74$, $77,81]$ the less absorbent and more efficient refractory felts made of carbon ([24], Fig. 12 [75, 76]) or calcia stabilized zirconia ([113], Fig. 12) can be employed.

Since no solution can totally avoid thermal gradients in the scattering zone, their experimental estimation is important. This approach, already achieved by several authors [29, 42-44] has been applied to our own device (Fig. 12). Power consumption $P$ (watt) as a function of temperature $T(\mathrm{~K})$ can be written as follows : $P=\alpha\left(T-T_{0}\right)+\beta\left(T^{4}-T_{0}^{4}\right)$ with $T_{0}$ room temperature; $\alpha\left(T-T_{0}\right)$ is related to conduction and convection heat transfers and $\beta\left(T^{4}-T_{0}^{4}\right)$ to radiative heat transfers from the Stefan-Boltzmann relation; $\alpha$ and $\beta$ experimentally deduced are respectively 0.048 and $3.48 \times 10^{-11}$ when a zirconia sample is inside the resistor, 0.143 and $2.45 \times 10^{-11}$ without the sample. These results, drawn on figure 14 , show that :

- small powers are required for high temperature production $\left(1.4 \mathrm{~kW}\right.$ at $\left.2200^{\circ} \mathrm{C}\right)$;

- conduction and convection losses constitute a tiny part of the total power consumption $(0.1 \mathrm{~kW}$ at $\left.2000^{\circ} \mathrm{C}\right)$ even in the $\mathrm{He}$ atmosphere $(\simeq 1.3 \mathrm{~atm}$.);

- at equal temperatures, convection losses reduce whilst radiative losses increase when a sample is inside the furnace.

Thermal gradients have been estimated using $\mathrm{W} / \mathrm{W}$ - Re thermocouples up to $1900^{\circ} \mathrm{C}$ and (or for higher temperatures) nearly blackbody graphite cavities inside the resistor at various positions along the 


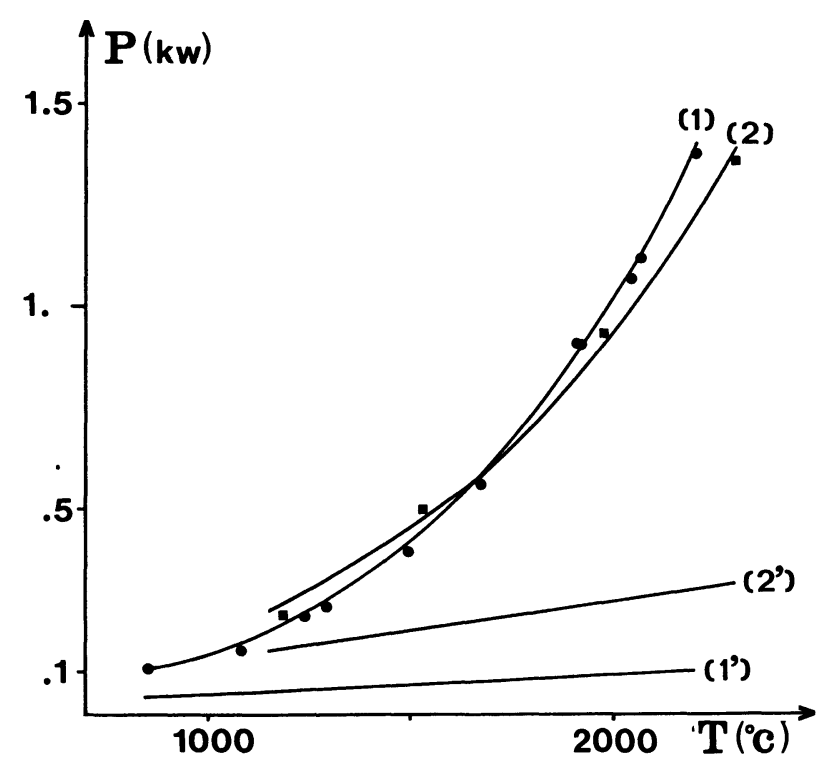

Fig. 14. - High temperature neutron scattering device power consumption $[75,76]$ :

- upper curves respectively refer to total furnace power consumption with (1) and without (2) sample inside the resistor,

- lower curves refer to added conduction and convection power consumptions with (1') and without (2') sample.

sample zone. It appears that gradients in the scattering zone $h$ (Figs 11-12) are of the order of $10^{\circ} \mathrm{C}$ in the whole range of temperature (Table I), radial gradients, minimized by the sample rotation, can be ignored. All uncertainties that affect the real temperature determination are detailed in table I. The total temperature uncertainty, around $20^{\circ} \mathrm{C}$ below $1900{ }^{\circ} \mathrm{C}$ and $30^{\circ} \mathrm{C}$ above, agrees well with those of several reliable works $[29,42,43,47]$.

\section{Chemical reactivity.}

Chemical reactivity of the sample at high temperature during scattering experiments is an extremely important point $[87,114]$ as well as the intrinsic sample behaviour with temperature (decomposition, volatilization), specific chemical reactions between the sample and its environment are involved, suggesting the following two distinctions :
- chemical reactions of the sample with its holder or with the heating element when in contact;

- chemical reactions with the gaseous medium, controlled or not.

Only self supported samples, generally used with radiation heating devices [30,31] can be free from chemical pollution in the first case. Otherwise great care must be taken in order to determine the more chemically resistant sample-holder (or heating element) couple for scattering experiments at the desired temperatures. This problem has already partly been discussed in section 3.1 (coating of high temperature thermocouples). In our experimental work we have been induced to use several sample supports (W, $\alpha \mathrm{Al}_{2} \mathrm{O}_{3}$, C.S.Z.) fitted in the coolest part of the samples below the scattering zone (Figs 10 and 11). However sometimes the chemical reaction can be the purpose of the experiment : an example is provided by the high temperature X-ray device designed by Pialoux et $a l$. [115] in order to study the carburation of refractory oxides.

The second case mainly applies to non stoichiometric refractory carbides or refractory fluorite type oxides such as $\mathrm{ZrO}_{2}, \mathrm{UO}_{2}$ or $\mathrm{ThO}_{2}$. The gaseous environment of samples which are not encapsulated in a hermetically sealed can, is generally of importance if materials like $\alpha \mathrm{Al}_{2} \mathrm{O}_{3}$, which is insignificantly affected by atmosphere until its melting point $[97,112$, 116], are excepted. Then conditionned by the purpose of the scattering experiment, controlled reducing, neutral or oxidizing atmospheres can be a necessity. Reducing or neutral atmospheres can be achieved by lowering the oxygen partial pressure by means of gas mixtures, such as $\mathrm{CO} / \mathrm{CO}_{2}$ : a controlled atmosphere neutron diffraction furnace (maximum temperature $1500^{\circ} \mathrm{C}$ ) has already been constructed [117]. An other type of atmosphere control, especially suitable for oxidizing atmospheres, can rather easily be achieved with radiation heated devices as demonstrated by Revcolevschi et al. [30, 31, 108]. Most of the furnaces described here work under uncontrolled atmosphere as well as under vacuum. In the latter case the volatilization rate of some materials such as $\mathrm{UO}_{2}[118]$ is greatly enhanced. This is the reason why we have worked under gas pressure, somewhat uncontrolled but generally slightly neutral or reducing [74-76].

Table I. - Significant contributions to the whole uncertainty on the sample real temperature determination.

\begin{tabular}{|l|c|c|}
\hline \multicolumn{1}{|c|}{ origins of the uncertainties } & from $850^{\circ} \mathrm{C}$ to $1900^{\circ} \mathrm{C}$ & above $1900{ }^{\circ} \mathrm{C}$ \\
\hline $\begin{array}{l}\text { reading on the pyrometer } \\
\text { equivalent emissivity }(0.84 \pm 0.01)\end{array}$ & scales I and II $: \pm 5^{\circ} \mathrm{C}$ & scale III : $\pm 10^{\circ} \mathrm{C}$ \\
thermal gradient & $\pm 1^{\circ} \mathrm{C}$ to $\pm 3^{\circ} \mathrm{C}$ & $\sim \pm 5^{\circ} \mathrm{C}$ \\
fluctuations with time & $\pm 5^{\circ} \mathrm{C}\left(\right.$ above $\left.1700^{\circ} \mathrm{C}\right)$ & $\sim \pm 10^{\circ} \mathrm{C}$ \\
\hline whole uncertainty & $\pm 15^{\circ} \mathrm{C}$ to $\pm 20^{\circ} \mathrm{C}$ & $\sim 10^{\circ} \mathrm{C}$ \\
\hline
\end{tabular}


Table II. - Neutron beam attenuation by several metals that can be used in a high temperature Joule heated neutron scattering device.

\begin{tabular}{|l|c|c|c|c|}
\hline \multirow{2}{*}{ Elements } & Utilization & \multicolumn{2}{c|}{$\begin{array}{c}\text { Whole } \\
\text { thickness } \\
(\mathrm{mm})\end{array}$} & \multicolumn{2}{|c|}{$\begin{array}{c}\text { Neutron beam attenuation (\%) } \\
\lambda=2.4 \AA\end{array}$} & $\lambda=5 \AA$ \\
\hline Aluminium & Furnace enclosure & 2 & 0.35 & 0.7 \\
\hline Molybdenum & resistor and shields & 0.28 & 0.6 & 1.2 \\
Tungsten \\
Rhenium
\end{tabular}

Table III. - Significant physical properties of refractory elements that can be used as resistive heaters above $2000^{\circ} \mathrm{C}$.

\begin{tabular}{|c|c|c|c|c|c|c|c|}
\hline \multirow[t]{2}{*}{ Elements } & \multirow{2}{*}{$\begin{array}{c}\text { Melting } \\
\text { temperature } \\
\left({ }^{\circ} \mathrm{C}\right)\end{array}$} & \multirow{2}{*}{$\begin{array}{l}\text { Vapour } \\
\text { Pressure } \\
\text { at } 2000^{\circ} \mathrm{C} \\
\text { (torr) }\end{array}$} & \multirow{2}{*}{$\begin{array}{l}\text { Resistivity } \\
\text { at } 20^{\circ} \mathrm{C} \\
(\mu \Omega \times \mathrm{cm})\end{array}$} & \multicolumn{2}{|c|}{$\begin{array}{l}\text { True absorption } \\
\text { cross section } \\
\sigma_{\mathrm{a}}\left(10^{-24} \mathrm{~cm}^{2}\right)\end{array}$} & \multicolumn{2}{|c|}{$\begin{array}{l}\text { Scattering cross section } \\
\qquad\left(10^{-24} \mathrm{~cm}^{2}\right)\end{array}$} \\
\hline & & & & $\lambda=2.4 \AA$ & $\lambda=5 \AA$ & coherent $\left(4 \pi b^{2}\right)$ & total \\
\hline Iridium & 2410 & $2.5 \times 10^{-5}$ & 4.9 & 578 & 1204 & 14.12 & \\
\hline Niobium & 2468 & $2.5 \times 10^{-6}$ & 14 & 1.4 & 2.9 & 6.35 & 6.6 \\
\hline Molybdenum & 2617 & $2 \times 10^{-5}$ & 5.26 & 3.1 & 6.5 & 5.95 & 6.1 \\
\hline Tantalum & 2996 & $2.2 \times 10^{-8}$ & 12.4 & 28.9 & 60.2 & 6.1 & 6 \\
\hline Osmium & 3045 & $2 \times 10^{-6}$ & 9.5 & 20 & 41.7 & 14.39 & 14.9 \\
\hline Rhenium & 3180 & $2.3 \times 10^{-8}$ & 19.3 & 111 & 231 & 10.64 & \\
\hline Tungsten & 3410 & $1.2 \times 10^{-9}$ & 5.58 & 24.4 & 51 & 2.86 & 5.7 \\
\hline Graphite & $\begin{array}{c}3550 \\
\text { (sublimation) }\end{array}$ & $\begin{array}{l}2.3 \times 10^{-7} \\
\left(\text { at } 2300^{\circ} \mathrm{C}\right)\end{array}$ & 1375 & 0.007 & 0.014 & 5.50 & 5.51 \\
\hline
\end{tabular}

\section{Conclusions.}

It appears that reliable high temperature scattering experiments can be performed above $2000^{\circ} \mathrm{C}$. Nearly all of what could be done with X-rays in that field has already been achieved (for instance an X-ray diffraction chamber heated with an electron beam has been commercialized in the past [119]). Forthcoming improvements can now mainly arise from new $\mathrm{X}$-ray sources (synchrotron radiation) and progress in detection techniques (linear or two-dimensional detectors) as well as in data acquisition (computers). Because of neutron specific properties important improvements for very high temperature investigations can reasonably be forecasted. Their low absorption by matter allows the construction of versatile high performance temperature devices (Table II), since numerous materials can be used as heating elements (Table III). In addition the neutron scattering field of investigation is far more extensive compared to $\mathrm{X}$-rays since it is not only restricted to determination of the high temperature structure of molten alloys [69,71-73], and refractory oxides such as $\mathrm{Ln}_{2} \mathrm{O}_{3}$ [120], $\mathrm{UO}_{2}$ and
$\mathrm{ThO}_{2}$ [77-79] but can be extended to dynamic studies, inelastic [77-79] or quasi-elastic scattering (QNS) for example the study of oxygen diffusive motion in the high temperature structures of $\mathrm{La}_{2} \mathrm{O}_{3}$ [121].

Future trends in high temperature scattering experiments depend both on improvements in neutron technologies and on the design of new generations of high temperature devices. Higher flux of thermal neutrons and more and more efficient multidetectors will enable faster experiments with simultaneous collection of all the data, a favourable situation for extremely high temperature experiments. Simple improvements of already existing devices are still possible, depending upon the type of experiment to be performed, for instance controlled atmosphere furnaces seem desirable. New high temperature devices inspired from X-ray experiments can be constructed, for instance radiation heated devices. Joule heated furnaces with non metallic heaters can also be envisaged : graphite furnace [122] can work up to $3000^{\circ} \mathrm{C}$ under vacuum or reducing atmosphere, stabilized zirconia furnaces [123-125] can work up to about $2200^{\circ} \mathrm{C}$ in oxidizing atmosphere. All these future 
developments are at the present time interesting for the most widely studied type of materials such as nuclear fuels based upon $\mathrm{UO}_{2}$ and $\mathrm{ThO}_{2}$, refractory strategic materials (W, Mo, Ta, Nb) or ceramics with thermomechanical properties, for instance refractory carbides and nitrides and partially stabilized zirconia (PSZ).

\section{Acknowledgments.}

The author is grateful to Dr. Badie, Dr. Laugier, Dr. Minato, Prof. Revcolevschi and especially to Prof. Traverse for documents and discussions. Technical and human support from the I.L.L. is acknowledged.

\section{Reference}

[1] Kieffer, R., Leimer, G. et Gugel, E., Powder Metall. Int. 4 (1972) 198-200.

[2] Urbain, G. et Rivot, M., Les hautes températures II (Chaudron, G. et Trombe, F.) (Masson, Paris) 1973 , p. $85-103$.

[3] Ackermann, R. J. et Rauh, E. G., J. Chem. Thermodin. 3 (1971) 445-460.

[4] Flahaut, J. et Souleau, Ch., Les hautes températures II (Chaudron, G. et Trombe, F.) (Masson, Paris) 1973, p. 105-132.

[5] Heetderks, H. D., Rudy, E. et Eckert, T., Planseeber. Pubvermetall. 13 (1965) 105-125.

[6] Kocherzhinsky, J. A., Colloq. Int. CNRS, № 205 (1972) 47-51.

[7] Djemal, M. et Dode, M., Rev. Int. Htes Temp. Réfract. 11 (1974) 249-252.

[8] Rauh, E. G. et Ackermann, R. J., Can Metall. $Q$. 14 (1975) 205-211.

[9] Shpil'rain, E. E., Kagan, D. N., Barkhatov, L. S., Zhmakin, L. I. et Koroleva. V. V.. High Temp. High Press. 11 (1979) 539-542.

[10] Anthony, A. M., Les hautes températures II (Chaudron, G. et Trombe, F.) (Masson, Paris) 1973, p. 241-264.

[11] Hust, J. G., High Temp. High Press. 8 (1976) 377390.

[12] Sphpil'rain, E. E., Kagan, D. N., Barkhatov, L. S. et Zhmakin, L. I., High Temp. High Press. 8 (1976) 177-181.

[13] Barkhatov, L. S., Zhmakin, L. I., Kagan, D. N., Koroleva, V. V. et Shril'rain, E. E., High Temp. High Press. 13 (1981) 39-42.

[14] Cabannes, F., Les hautes températures II (Chaudron, G. et Trombe, F.) (Masson, Paris) 1973, p. 299-337.

[15] Cabannes, F., High Temp. High Press. 8 (1976) 155156.

[16] Maglic, K. D., Perovic, N. et Zivotic, Z., High Temp. High Press. 12 (1980) 555-560.

[17] Christensen, J. A., Report HW-75148 Hanford Atomic Products Operation Richlan, Washington (1962).

[18] KNIBBS, R. H., J. Sci. Instrum. 2 (1969) 515-517.

[19] Petukhov, V. A. et Chekhovskoi, V. Y., High Temp. High Press. 4 (1972) 671-677.

[20] Fitzer, E., Agard Advisory Report No 38, Project Section 1B (1972).

[21] Fitzer, E., Weisenburger. S., Rev. Int. Hautes Temp. Refract. 12 (1975) 69-73.

[22] Edwards, J. W., Speiser, R. et Johnston, H. L., Phys. Rev. 73 (1948) 1251.

[23] Edwards, J. W., Speiser, R. et Johnston, H. L., J. Appl. Phys. 22 (1951) 424-428.
[24] Bowman, M. G., Hull, D. E., Witteman, W. G., Arnold, G. P. et Bowman, A. L., Rev. Sci. Instrum. 37 (1966) 1543-1544.

[25] Edwards, J. W., Speiser, R. et Johnson, H. L., Rev. Sci. Instrum. 20 (1949) 343-347.

[26] Bowman, A. L., Krikorian, N. H., Nereson, N. G. et RuPERT, G. N., Colloq. Int. CNRS No 205 (1972) 193-197.

[27] Debrenne, P., Chaudet, M. et Laugier, J., Colloque sur les méthodes analytiques par rayonnement $X$, C.G.R., Montpellier (1969) 9-13.

[28] Debrenne, P., Laugier, J. et Chaudet, M., J. Appl. Crystallogr. 3 (1970) 493-496.

[29] Stecura, S., Rev. Sci. Instrum. 39 (1968) 760-765.

[30] Revcolevschi, A., Rev. Int. Htes Temp. Réfract. 7 (1970) 73-90.

[31] Hubert, J., Revcolevschi, A. et Collongues, R., Can. Metall. Q. 13 (1974) 361-364.

[32] Noguchi, T., Colloq. Int. CNRS No 205 (1972) 347349.

[33] Hanic, F., Stracelsky, J. et Sumichrast, L., Colloq. Int. CNRS № 205 (1972) 129-132.

[34] Gubser, R. A., Hoffmann, W. et Nissen, H. U., Zeit. Krist. 119 (1963) 264-272.

[35] Nukui, A. et IwaI, S. I., Rev. Sci. Instrum. 43 (1972) 1299-1301.

[36] Miyata, T., Ischizawa, N., Minato, I. et Iwai, S. I., J. Appl. Crystallogr. 12 (1979) 303-305.

[37] Ischizawa, N., Miyata, T., Minato, I., Marumo, F. et IwaI, S., Acta Crystallogr. B 36 (1980) 228-230.

[38] Nukui, A., Tagai, H., Morikawa, H. et Iwai, S. I., J. Am. Ceram. Soc. 59 (1976) 534-536.

[39] Minato, I. (private communication) (1984).

[40] Matuyama, E., J. Sci. Instrum. 32 (1955) 229-231.

[41] Chiotti, P., Rev. Sci. Instrum. 25 (1954) 683-688.

[42] Baker, T. W., Baldock, P. J. et SpindleR, W. E., U.K.A.E.A. Report AERE, R4556 (1965).

[43] Baker, T. W., Baldock, P. J. et Spindler, W. E., J. Sci. Instrum. 43 (1966) 803-808.

[44] Houska, C. R. et Keplin, E. J., J. Sci. Instrum. 41 (1964) 23-27.

[45] Boganov, A. G., Rudenko, V. S. et Makarov, L. P., Dokl. Akad. Nauk. SSSR 160 (1965) 1065-1068.

[46] Guichet, L., Delmas, R. et Trillat, J. J., C.R. Hebd. Séan. Acad. Sci. 262B (1966) 968-973.

[47] Guichet, L. et Trillat, J. J., Colloq. Int. CNRS № 205 (1972) 115-127.

[48] Steward, E. G., CooK, B. P. et Kellett, E. A., Nature 187 (1960) 1015-1016.

[49] Kellett, E. A. et Steward, E. G., J. Sci. Instrum. 39 (1962) 306-308.

[50] YANG, K. T., Proc. 5th Carbon Conf. (1961) 492-496. 
[51] Braun, W., Christu, N. et Fitzer, E., Rev. Int. Htes Temp. Refract. 7 (1970) 257-263.

[52] Fitzer, E. et Weisenburger, S., High Temp. High Press. 5 (1973) 327-330.

[53] Fitzer, E. et Weisenburger, S., Colloq. Int. CNRS No 205 (1972) 205-215.

[54] Maire, J. et Rogue, J., Colloq. Int. CNRS № 205 (1972) 217-220.

[55] Intrater, J. et Hurwitt, S., Rev. Sci. Instrum. 32 (1961) 905-906.

[56] Smith, D. K., Norelco Rep. 10 (1963) 19-29.

[57] Traverse, J. P., Badie, J. M. et FoeX, M., Colloq. Int. CNRS No 205 (1972) 139-147.

[58] Traverse, J. P. et Badie, J. M., 3rd Int. Conf. on Chem. Therm., Baden, Austria (1973) 122-129.

[59] Traverse, J. P. et Foex, M., 7th Colloque d'analyse par diffractométrie et spectrométrie de rayons $X$, Lyon (1967) 13-19.

[60] Campbell, W. J., Stecura, S. et Grain, C., U.S. Bur. Mines Rept. Invest. No 5738 (1961).

[61] Campbell, W. J., Stecura, S. et Grain, C., Advances in $X$-ray analysis, Vol. 5 (Plenum Press, New York) 1962 , p. 169.

[62] Goldschmidt, H. J., Bibliography 1, I.U. Cr. Commission on Crystallographic Apparatus (1964).

[63] Kocherzhinskil, Y. A. et Pet'kov, V. V., Sov. Powder Metall. Met. Ceram. 5 (1970) 422-432.

[64] Traverse, J. P., Rev. Int. Htes Temp. Refract. 10 (1973) 125-129.

[65] LeHR, P., Les hautes températures II (Chaudron, G. et Trombe, F.) (Masson, Paris) 1973, p. 160-188.

[66] Huber, M., Les hautes températures II (Chaudron, G. et Trombe, F.) (Masson, Paris), 1973, p. 339-350.

[67] Tourand, G. et Breuil, M., Colloq. Int. CNRS № 205 (1972) 199-203.

[68] Bellissent, R. (private communication) (1984).

[69] Lemarchand, J. L., Thèse Doct. Ing., Grenoble (1978) 64-70.

[70] Kunsch, B., Eder, O. J., Erdpresser, E. et Stiller. H., J. Phys. E. 12 (1979) 587-588.

[71] TAVERnière, P., Thèse 3e cycle, Grenoble (1981) 49-54.

[72] Bletry, J., Tavernière, P., Senillou, C., Desré, P., Maret, M. et Chieux, P., Revue Phys. Appl. (this issue).

[73] Freyland, W., Hensel, F. et Glaser. W., Ber. Bunsenges. Phys. Chem. 83 (1979) 884-889.

[74] Aldebert, P., Badie, J. M., Traverse, J. P., Buevoz, J. L. et Roult, G., Rev. Int. Htes Temp. Refract. 12 (1975) 307-319.

[75] Aldebert, P., Thèse No 928, Toulouse (1980) 45-57.

[76] Aldebert, P. et Traverse, J. P., High Temp. High Press. 13 (1981) 251-262.

[77] Clausen, K., Hayes, W., MacDonald, J. E., SchnaBel, P., HutChings, M. T. et KJEMS, J. K., High Temp. High Press. 15 (1983) 383-390.

[78] Clausen, K., Hayes, W., MacDonald, J. E., Osborn, R. et Hutchings, M. T.. AERE Report MPD/ NBS/245 (1983).

[79] Hutchings, M. T., Clausen, K., Hayes, W., MacDonald, J. E., Osborn, R. et Schnabel, P., Revue Phys. Appl. (this issue).

[80] THE SAMPLE ENVIRONMENT GROUP NEUTRON DIVISION, Revue Phys. Appl. (this issue).

[81] ILL NEUTRON BEAM FACILITIES AVAILABLE FOR USERS, Edition December (1983) (available at the ILL Scientific Secretary) 116.
[82] Bowman, A. L. et Arnold, G. P., " High Temperature neutron diffraction studies" in Adv. High Temp. Chem. № 4 (Academic Press New York) 1971.

[83] Cabannes, F., Lacroix, R. et Urbain. G.. Le's hautes températures II (Chaudron, G. et Trombe F.) (Masson, Paris) 1973, p. 25-60.

[84] Ribaud, G., Traité de pyrométrie optique (Editions de la Revue d'Optique Théorique et Instrumentale) Paris, 1931

[85] Sata, T., Rev. Htes Temp. Réfract. 3 (1966) 337-341.

[86] Kenisarin, M. M., Chekhovskoi, V. Y., Berezin, B. Y. et Kats, S. A., High Temp. High Press. 8 (1976) 367-376

[87] Alcock, C. B., High Temp. High Press. 11 (1979) 241249.

[88] Caers, J., Casteels, F. G. et Brabers, M. J., High Temp. High Press. 12 (1980) 411-418.

[89] Chrétien, A. et Freundlich, W., Nouveau traité de Chimie Minérale XIV (Pascal, P.) (Masson, Paris), 1959 , p. 825-833.

[90] Watson, M. D., Hill, D. N. et Chapman, A. T., J. Am. Ceram. Soc. 53 (1970) 112-113.

[91] Johnson, T. A. et Benzel, J. F., J. Am. Ceram. Soc. 56 (1973) 234

[92] Kamenetskil, A. B., Gul'ko, N. V. et Gladkaya, N. V., Ogneupory 5 (1970) 50-53.

[93] Thomas, D. B., J. Res. N.B.S. 66C (1962) 255-260.

[94] Walker, R. F., Rev. Htes Temp. Refract. 3 (1966) 301-308.

[95] Ribaud, G., Mesure des températures (3e édition) (Colin. Paris) 1948

[96] Cabannes, F., Lacroix, R. et Urbain, G., Les hautes températures II (Chaudron, G. et Trombe, F.) (Masson, Paris) 1973, p. 61-83.

[97] Schneider, S. J. et McDaniel, C. L., J. Res. N.B.S. 71A (1967) 317-333.

[98] Cabannes, F., Les hautes températures II (Chaudron, G. et Trombe, F.) (Masson, Paris) 1973, p. 189-224.

[99] Ziegler, W. G., Speiser, J. R. et Johnston, H. L., Rev. Sci. Instrum. 20 (1949) 367.

[100] Ackermann, R. J., Garg, S. P. et Rauh, E. G., $J$. Am. Ceram. Soc. 60 (1977) 341-345.

[101] ShPil'rain, E. E., Yakimovich, K. A. et Tsitsarkin, A. F., High Temp. High Press. 5 (1973) 191-198.

[102] Schneider, S. J. et McDaniel, C. L., Rev. Htes Temp. Réfract. 3 (1966) 351-361.

[103] Foex, M., Rev. Htes Temp. Réfract. 3 (1966) 309-326.

[104] Riley, B., Rev. Htes Temp. Réfract. 3 (1966) 327-336.

[105] QuinN, T. J., High Temp. High Press. 12 (1980) 359372.

[106] Cabannes, F., Rev. Htes Temp. Réfract. 3 (1966) 101 107.

[107] Traverse, J. P. et Foex, M., Rev. Gen. Electr. 79 (1970) 819-821.

[108] Revcolevschi, A., Hubert, J., Collongues, R., C.R. Hebd. Séan. Acad. Sci. 269C (1969) 265-268.

[109] Handbook of chemistry and Physics 55th édition (CRC press) 1974-1975, E-217.

[110] Urbain, G. et Rouannet, M., Rev. Hes Temp. Réfract. 3 (1966) 363-369.

[111] Fitzer, E. et Weissenburger, S., High Temp. High Press. 4 (1972) 559-571.

[112] Aldebert, P. et Traverse, J. P., High Temp. High Press. (in press). 
[113] McDonald, B. P., Schaffer, P. C. et Cummerrow, [120] Aldebert. P. et Trayersf. J. P., Mater. Res. Bull. 14 R. L., Ceramic age (1971) 24-25. (1979) 303-323.

[114] Alcock, C. B., Colloq. Int. CNRS No 205 (1972) [121] Aldebert, P., Dianoux, A. J. et Traverse, J. P., 223-233. J. Physique 40 (1979) 1005-12.

[115] Pialoux, A. et Dode, M., Rev. Int. Hies Temp. [122] Marsh, H., Wynne-Jones, W. F. K., J. Sci. Instrum. Réfract. 8 (1971) 155-160.

[116] Aldebert, P. et Traverse, J. P., J. Am. Ceram. Soc. 65 (1982) 460-464 42 (1965) 710-711.

[117] Carel, C., Hubert, L., Gobert, G., Tardiff, P. et Chancel, L., Appl. Optics 16 (1977) 1275-79.

[123] Faucher, M., Dembinski, K., Anthony, A. M., Rev. Int. Htes Temp. Réfract. 6 (1969) 17-23.

[118] Tetenbaum, M. et Hunt, P. D., J. Nucl. Mater. 34 (1970) 86-91.

[119] MRC Manufacturing Corporation, Rev. Sci. Instrum. 36 (1965) 124.

[124] Rothwell, E., Rev. Int. Htes Temp. Réfract. 10 (1973) 31-36.

[125] Anthony, A. M., Les hautes températures II, Chaudron, G. et Trombe, F. (Masson, Paris) 1973, p. 519-540. 